\title{
Prospects of Nanobioremediation in Environmental cleanup
}

\author{
GARIMA PANDEY* \\ Department of Applied Sciences, SRM Institute of Science and Technology, Tamil Nadu 603203, India. \\ *Corresponding author: garimapandey.pandey8@gmail.com \\ http://dx.doi.org/10.13005/ojc/340622
}

Received: November 04, 2018; Accepted: December 10, 2018)

ABSTRACT

\begin{abstract}
This century is struggling with the issue of environment friendly management of the pollutants which are contaminating the environment. One of an ecofriendly and economically feasible method is the bioremediation of pollutants using bio nanoparticles. Nanobioremediation is a highly studied and explored area of remediation of contaminants using nanotechnology. Nanoparticles used for bioremediation are biologically synthesized from plant extracts, fungi and bacteria. These biogenic nanoparticles when applied to environmental contaminants had shown very promising results. Based on the various studies the bioremediation of pollutants using biosynthetic nanoparticles is emerging as a very promising and sustainable method of environment cleanup. This review focuses on the synthesis of bio-nanoparticles and their use in cleaning the environment.
\end{abstract}

Keywords: Nano-bioremediation, Sustainable, Biogenic, Eco-friendly, Nano-particles.

\section{INTRODUCTION}

Some nanoparticles are found to produce inhibitory effect on seed germination and root growth; some of them are used for cleanup of Uranium contaminated waste water.

Green chemistry is the field of science reflecting the application of sustainable principles for the processes, reactions and procedures for synthesizing chemicals. ${ }^{1}$ It is an environment friendly method of producing materials which are less harmful because of the use of ecofriendly reactants. Now when the principle of green chemistry is applied for the production of Nanoparticles it is been found very promising. This green approach for the synthesis of nanomaterials ${ }^{2}$ is found to reduce the critical hazards of contaminants and benefit environmental and medicine segments of bionanotechnology in future. Green nanotechnology is the combination of Nanotechnology and Green chemistry reflecting the goal of creating ecofriendly nanomaterials and finding their applications for reducing environment and human health hazards. The enormous industrial expansion in the last century has changed the course of technological development and has changed the fate of human existence too. The innovation and expansion in the field of science and technology contribute directly or indirectly to the mammoth increase in waste and toxic substances in the environment. The neglectance of the effect of improper disposal and dissemination of

This is an Open Access article licensed under a Creative Commons license: Attribution 4.0 International (CC- BY). Published by Oriental Scientific Publishing Company @ 2018 
the materials in the environment had led to a toll on environmental health and because of this negligence several serious issues related to health have been reported. To protect the environment it is necessary maintain the environmental sustainability which involves conservation, protection and restoration of the natural environment maintaining the long term environmental quality. Thus, the efforts and research to grow technologies for the remediation of contaminated sites as well as to reduce the cost of the decontamination processes is increasingly encouraged. Several in-situ and ex-situ technologies are being deployed for decontamination. For in-situ treatment, soils are not being excavated and for ex-situ treatment first the contaminated soil is removed and treatment is performed off-site under controlled conditions ${ }^{2}$. Among the current methods of in-situ remediation, the use of nanomaterials has been highly appreciated and encouraged as a cost-effective and sustainable method. ${ }^{3-5}$

\section{Green synthesis of nanoparticles Nanoparticles from phytochemicals}

The unique catalytic, magnetic, electronic, optical and mechanical properties of Nanoparticles are attracting scholars to find new routes for their synthesis. Green synthesis is an innovative method of synthesizing nanoparticles ${ }^{6}$ keeping in mind the environmental sustainability and environmental hazards. Out of all the practiced methods of synthesizing nanoparticles the green route is most advantageous. It is because of its cost effectiveness, eco-friendly approach, controlled toxicity and rapid speed of reaction etc. Nanoparticles synthesized by green route have a well defined structural, physical and chemical properties ${ }^{7,8}$ There are two methods for synthesizing nanoparticles, the chemical synthesis and the green synthesis ${ }^{9-10}$. Chemical Synthesis of nanoparticles uses chemical reduction using chemical compounds such as citrates, ascorbates, borohydrates of sodium ${ }^{11-13}$ etc . Chemical synthesis of nanoparticles uses toxic solvents, ${ }^{14-15}$ extreme physical conditions like high temperature, pressure, ${ }^{16-18}$ energy is required which all is not ecofriendly and poses serious threats to environmental balance ${ }^{19-21}$

Green synthesis of nanoparticles uses green reducing agents ${ }^{22-25}$ which are obtained from phytochemical ${ }^{26}$ extracts of different plants such as extracts from plant leaves, juices from various medicinal plants etc. Green synthesis involves mixing of a fixed ratio of plant extract and metal ions providing them the adequate conditions and it has been reported that even at conditions as mild as room temperature these reactions show positive indications conforming the formation of nanoparticles 154,155. Once synthesized, the nanoparticles are characterized by UV, XRD and FTIR data analysis 27-32. Nanoparticles are categorized in two groups - organic and inorganic nanoparticles. Organic Nanoparticles are carbon made nanoparticles, mostly fullerenes whereas inorganic nanoparticles include noble metal nanoparticles eg. Gold and silver,semiconductor nanoparticles ${ }^{33-38}$ eg. Titanium dioxide, zinc oxide etc. Ruffin-castigline classified nanoparticles as natural, incidental and engineered nanoparticles, based on their method of origin. All the metal Nanoparticles are kept under the category of engineered nanoparticles because all of are being synthesized in laboratories eg. Nanogold, $\mathrm{ZnO}, \mathrm{TiO}_{2}$, Quantum dots etc et-42. $^{39}$.

The antimicrobial activity of SilverNPs and their use in batteries, optical receptors has made the scientists to biologically synthesize them. Ag NP can be biosynthesized from the phytoextracts of various plants like Sinapis arvensis, Lantana camara, Trigonella foenumgraecum, Artemisia nilagirica, Nerium oleander, Pithophora oedogonia83110 etc. Gold NPs were synthesized from the plant extracts of Abelmoschus esculentus, Angelica, hypericum, Eucalyptus, Mentha, Zingiber officinale etc ${ }^{119-143}$.Iron NPs are being synthesize using the phytoetracts obtained from the plants such as Aloe vera, Rosemarinus officinalis, Green tea, Dodonaea viscose ${ }^{144-152}$ etc. Likewise CopperNPs are synthesized from leaf extracts of Punica granatum, Ocimum tenuiflorum, Nerium oleander, Ricinus communis ${ }^{173-185}$, ZincNPs, and PalladiumNPs have been biologically synthesized using plant extracts from tea and coffee, Cinnamomum camphora, Melia azedarach, Delonix regia and Evolvulus alsinoides etc. ${ }^{158-166,195-212}$.

\section{Nanoparticles from microbes}

Microorganisms have the potential to reduce metal ions leading to the synthesis of nanoscale materials. Microorganisms secrete extracellular enzymes which are being used for the synthesis of relatively pure nanoparticles ${ }^{111-118}$. Bacteria have special affinity for metals and this unique metal binding property makes them useful 
for nanobioremediation. Apart from bacteria, fungi and yeast are also being used for biosynthesis of nanoparticles ${ }^{129-139}$. Whenever it is required to synthesize large amounts of nanoparticles fungi are being used because of their characteristic property of larger volumes of proteins. Microbiological methods of synthesizing nanoparticles are comparatively slower than the methods using plant extracts ${ }^{140}$ ${ }^{141}$ Table 1. In biosgenic production of metal nanoparticles by a fungus, some reducing enzymes with catalytic effects are produced which reduce salts to their corresponding metallic solid nanoparticles. This catalytic effect is a major drawback of microbial synthesis of nanoparticles and needs to get rectified for the broader application of this method $^{153-157,167-172}$. Microbes have some advantages over other biological methods like these are easy to handle, have a high growth rate, low cost requirement, easy culture methods, less environmental hazards and these qualities of microbes make them useful for biosynthesis ${ }^{186-194}$. Yeast threads are also being use for the synthesis of nanoparticles. Many fungi are being used for the synthesis of nanoparticles fungi are better at producing a larger amount of nanoparticles as compared to bacteria because of the secreation of a large amount of protein producing higher amount of nanoparticles $200-205,213-215$. Using fungi for synthesizing nanoparticles is an ecofriendly route of nanoparticle synthesis.

Table 1: Biosynthesis of nanoparticles from plants and microbes

\begin{tabular}{|c|c|c|}
\hline \multicolumn{3}{|c|}{ Name of bio specie with reference } \\
\hline Name of NP & Plant & microorganism \\
\hline$\overline{\text { Siver NPs }}$ & 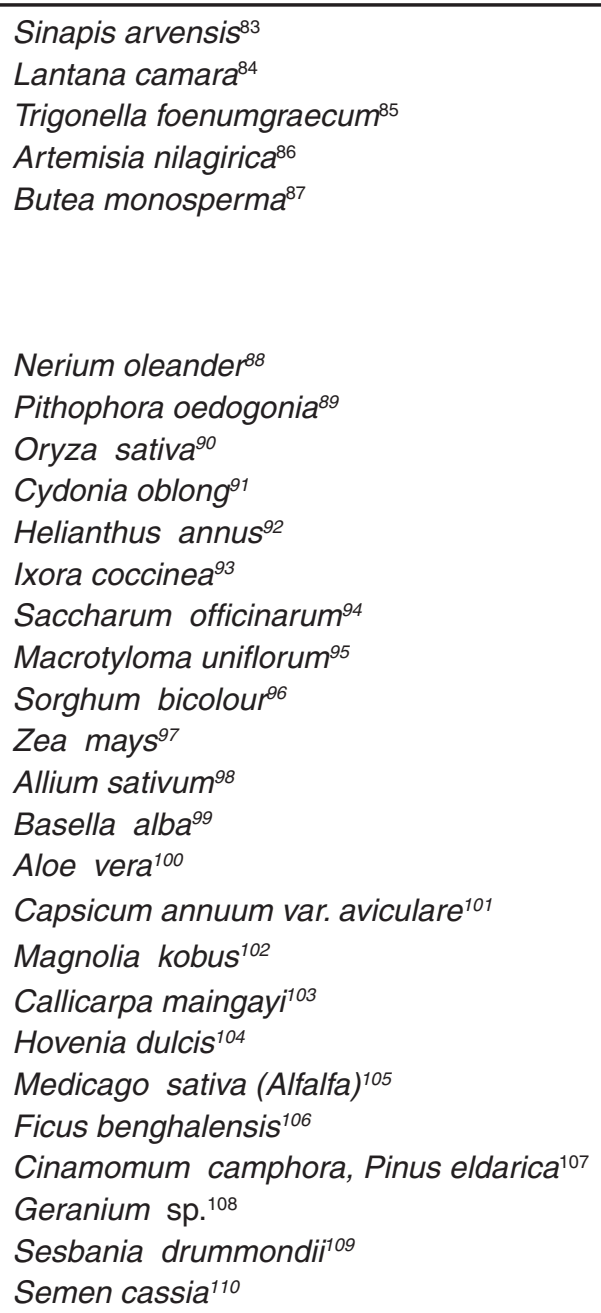 & $\begin{array}{l}\text { Staphylococcus aureus }{ }^{[111} \\
\text { Brevibacterium casei }^{112} \\
\text { Streptomyces } \mathrm{sp}^{113} \\
\text { Streptomyces naganishiil } \\
\text { Actinomycete, nocardiopsis sp. MBRC-1 }{ }^{115} \\
\text { Trichoderma reesei }{ }^{116} \\
\text { Cladosporium cladosporiodes }{ }^{117} \\
\text { Neurospora crassa }\end{array}$ \\
\hline
\end{tabular}


Gold NPs

Abelmoschus esculentus ${ }^{119}$

Angelica, Hypericum, Hamamelis ${ }^{120}$

Eucalyptus ,Ocimum, Mentha ${ }^{121}$

Stevia rebaudiana ${ }^{122}$

Zingiber officinale ${ }^{123}$

Terminalia chebula ${ }^{124,125}$

Morinda citrifolia L. ${ }^{126}$

Diopyros kaki i27

Anacardium occidentale ${ }^{1028}$

Jatropha waste ${ }^{142}$

Ginkgo Biloba ${ }^{143}$

Iron NPs Aloe vera ${ }^{144}$

Eucalyptus tereticornis ${ }^{145}$

Rosemarinus officinalis ${ }^{146}$

Green tea ${ }^{147}$

Dodonaea viscose ${ }^{148}$

Sorghum bran ${ }^{149}$

Caricaya papaya ${ }^{150}$

Sargassum muticum ${ }^{151}$

Azadirachta indica ${ }^{152}$

ZincNPs Aloe vera ${ }^{158,159}$

Limonia acidissima $^{160}$

Nyctanthes arbor-tristis ${ }^{161}$

Pongamia pinnata ${ }^{162}$

Parthenium hysterophorus ${ }^{163}$

Plectranthus amboinicus ${ }^{164}$

Trifolium pretense ${ }^{165}$

Ixora coccinea ${ }^{166}$

Copper NPs Punica granatum ${ }^{173}$

Ocimum tenuiflorum ${ }^{174}$

Nerium oleander ${ }^{175}$

Ricinus communis ${ }^{176}$

Ocimum sanctum ${ }^{177}$

Gloriosa superba ${ }^{178}$

Tabernaemontana divaricate ${ }^{179}$

Calotropis gigantean ${ }^{180}$

Ficus religiosa ${ }^{181}$

Carica papaya ${ }^{182}$

Rubus glaucus Benth ${ }^{183}$

Green tea and eucalyptus ${ }^{184,185}$

Titaniun Moringa oleifera ${ }^{195}$

Nyctanthes Arbor-Tristis ${ }^{196}$

Trigonella foenum-graecum ${ }^{197,198}$

Solanum trilobatum ${ }^{199}$

Aspergillus tubingensis ${ }^{[203}$

Palladium NPs tea and coffee 206

Origanum vulgare 207

Cinnamomum camphora ${ }^{208}$

Melia azedarach ${ }^{209}$

Delonix regia ${ }^{210}$
Rhodococcus sp. ${ }^{129}$

Klebsiella pneumonia ${ }^{130}$

Rhodopseudomonas capsulate ${ }^{131}$

Rhodococcus sp., Streptomyces sp. ${ }^{132}$

Streptomyces viridogens ${ }^{133}$

Nocardia farcinica ${ }^{134}$

Thermomonospora $\mathrm{sp}^{135}$

Cylindrocladium floridanum ${ }^{136,137}$

Aspergillus oryzae ${ }^{138}$

Neurospora crassa ${ }^{139}$

Penicillium brevicompactum ${ }^{140}$

Aspergillus clavatus ${ }^{141}$

Shewanella oneidensis ${ }^{153}$

Klebsiella oxytoca ${ }^{154}$

C. globosum ${ }^{155}$

E. coli ${ }^{156}$

Plerotus Sp. ${ }^{157}$

Lactobacillus $^{167,168}$

Streptomyces sp. ${ }^{169,170}$

Candida albicans ${ }^{171,172}$

Shewanella oneidensis ${ }^{186}$

Pseudomonas stutzeri ${ }^{187}$

Pseudomonas $s p$., Serratia $s p^{188}$

Streptomyces $s p^{189}$

Fusarium oxysporum ${ }^{190}$

Hypocrea lixii' ${ }^{191}$

Penicilium citrinum ${ }^{192}$

Sterium hirsutum ${ }^{193}$

Penicillium aurantiogriseum, Penicillium citrinum, Penicillium waksmanii ${ }^{194}$

Bacillus subtilis ${ }^{200}$

Bacillus amyloliquefaciens ${ }^{201}$

Aeromonas hydrophila202

Fusarium oxysporum 204,205

Desulfovibrio desulfuricans ${ }^{213,214}$

S. oneidensis 215 
Nano-remediation of the contaminated Sites

The industrial boom and population growth has introduced a wide range of pollutants such as hazardous heavy metals, various harmful inorganic compounds, organic pollutants and many other complex compounds in ground surface and ground water system ${ }^{43,44}$. It is vital to remove these toxic substances from the environment. Nanotechnology has been reported to play important role in addressing different effective and innovative solutions to many of the diverse environmental challenges ${ }^{45,46}$. Nanoremediation also can help in lowering down the level of pollutants in the environment ${ }^{47,48}$. Three major applications of nanoremediation include detection of pollution using nanosensors ${ }^{49,50}$, prevention of pollution ${ }^{51,52}$, purification and remediation of contamination ${ }^{53,54}$. In the past two decades due to the efficiency, cost effectiveness and eco-friendly nature ${ }^{55,56}$ the use of nano size particles has largely been encouraged as an alternative to existing treatment materials. Metals such as Iron, Palladium, Silver, Gold, in their elemental or zerovalent state in nanoscale form, because of their surface area charge crystallographic behavior and size specifications have shown promising results in the treatment of polluted sites contaminated with various toxic substances ${ }^{57-59}$. Iron nanoparticles are the first ones to be considered as a tool for environmental clean-up ${ }^{60-62}$. Environmental clean-up methods for the remediation of contaminated land or groundwater are using Iron either as a sorbent for adsorbing contaminants by injecting it into subsurface environments at the contaminated sites or as an electron donor to reduce contaminants into a less toxic form ${ }^{63-65}$. Few methods of decontamination use both the sorption and electron donor nature of iron nanoparticles ${ }^{66-67}$. Apart from IronNPs, ZincNPs, GoldNPs SilverNPs, CopperNPs are also ben extensively studied for their role as decontaminant 68,79 . Zinc nanoparticles as photocatalyst have the property to degrade organic dyes, phenolic and medicinal compounds ${ }^{70-72}$. Silver, Copper and Gold nanoparticles have shown promising results in the degradation of organic dyes into less toxic compounds ${ }^{73-74}$.

\section{Challenges with Nanoparticles}

Although nanoparticles have shown promising results in treating contaminated sites, there are few problems associated to their loss of reactivity with time, transportation and their effect on microorganisms ${ }^{75,76}$. Iron nanoparticles show a loss in their reactivity level after a certain period, show a blocking effect in the soil by clogging the pores of soil and restricting the passage of fluids, showed that stabilizers, such as lactate, can be used to increases the mobility of iron nanoparticle in turn felicitating their better transport in soil ${ }^{77,78}$. Another major issue with nanoparticles is their toxic effect on the growth of the microbial communities. Various studies under controlled conditions have been performed on the effect of nanoparticles on microbes and the results are found to be conflicting ${ }^{79}$. Some of the studies have shown inhibitory effects on microorganisms like Staphylococcus aureus and Escherichia coli ${ }^{80-82}$. Few other studies, have shown stimulating effect of nanoparticles as electron donors on microorganisms such as bacteria and methanogens ${ }^{215,216}$. Soil microorganisms are extremely important to the natural cycle of nutrients in the environment and they can also naturally degrade the organic contaminants or reduce and immobilize heavy metals. Thus, the drastic reduction of the microbial population can result in the weakening of the soil's resistence to the contamination ${ }^{217,218}$. The toxic effect of nanoiron can disrupt the cell membrane by producing reactive oxygen compounds causing death of microbial cell. Nanoiron compounds can also hinder absorption of nutrients through the cell membrane in microbes inhibiting their growth ${ }^{219,220}$. Iron nanocompounds have not shown to have any effect on the growth of fungul colonies ${ }^{221,222}$. It has been studied that the txoic effect of nanoparticles can be minimized by coating them with some organic polymers. Studies also have showed that microorganisms sometimes produce certain specfic enzymes and polysaccharides to resist and counter the toxicity of nanoparticle 223,224 .

\section{Nano-bioremediation}

While deciding the best suitable method for the remediation of contaminated sites various aspects like efficiency, cost effectivity, complexity, hazards, availability of resources, time consumed are carefully analysed and evaluated. It has been observed that using a single technology for the remediation of the contaminants may not be that appropriate for selection. Therefore it is essential to combine applications of multiple technologies to overcome the issues related to the application of a single method 225,226 . Nanobioremediation is one such method using the applications of physiochemical and biological methods and currently 
it is being highly studied in various contaminated sites. Nanobioremediation technique first uses nanomaterials to break the contaminants to a level favourable to biodegradation and then leads to biodegradation of the contaminants. For the nanobioremediation, cleanup of the contaminated water and land sites is being performed by the nanoparticles which are bioligicaly synthesized from phytoextracts or microorganisms. Zerovalent ironNPs are promising and imperative means of nanoremediation and have shown to effectively treat acidic-water contaminated with heavy-metals by adsorbing the heavy-metal pollutants on their surface 227,228 . CNTs have also been proven to be extremely effectual in the remediation of contaminated water owing to their exceptional affnity and adsorption-characteristics towards the pollutant molecules ${ }^{229,230}$. The high thermal and chemical stability of CNTs makes them an important replacement to activated-carbon for the removal of different organic and inorganic contaminations like lead, chromium and zinc. ${ }^{231-}$ ${ }^{233}$. Even though nanoremediation is effective in mine-water treatment, still there are several issues related to their toxic effects that need to be sorted ${ }^{39}$. Several nano-applications for ecoremediation are quickly growing from pilot scale to full scale accomplishment in treating environmentally demanding chlorinated sites. NanoscaleTiO ${ }_{2}$, CNTs, dendrimers, swellable organically-modified silica (SOMS) and metallo-porphyrinogens and potential are nanoproducts for remediation of pollutants in ex-situ or in-situ process ${ }^{234-236}$. $\mathrm{TiO}_{2}$ nanoparticles have the potential to remediate a range of chemical fertilizers, herbicides, insecticides and pesticides through the process of photo-catalysis and are tested for ex-situ management of infected ground-water resources as well ${ }^{237-240}$. Biologically synthesized NPs of iron, copper, titanium metals in combination of a metal-catalyst such as gold, Pt, Pd and nickel, increase the reaction rate of the redox-reaction.
Pd NPs have the property of catalyzing the reduction process of trichloroethene to ethane with no production of intermediary byproduct, as vinyl chloride. A parallel metal-glass fusion material, PalladiumOsorb is successfully tested and used for ex-situ remediation of chlorinated VOCs. ${ }^{241-244}$. Silica NPs help in remediation of lead245-249, zinc NPs for $\mathrm{CS}_{2}$ from air and nanocrystalline hydroxyl-apatite for removing lead and cadmium, zerovalent nanoiron, CNTs, fullerenes, $\mathrm{TiO}_{2}$ and $\mathrm{ZnO} \mathrm{NPs}$, and bimetallic nano-metals for remediation of DDT, carbamates, heavy metals like chromium, lead, arsenic and cadmium from soil ${ }^{250,251}$. Biologically synthesized Iron NPs and Iron-Pd NPs have shown wider application in treatment of dyes, hydrocarbons, 2,3,7,8-tetrachlorodibenzo-p dioxin, pesticides, TCE PCB and Lindane etc using bacterial metabolism ${ }^{252-254}$.

\section{CONCLUSION}

To conclude, it is very much necessary for mankind to use the environment sensibly and sustainably. For that, remediation of contaminated sites is also an integral part of this sensibility and is very much necessary. Although nanobioremediation is an interesting and feasible method for remediation using applications of nanotechnology, the safety concerns and health risks associated with their large scale production and usage are not fully assessed and managed. Going by the promising results in degradation of pollutants by biologically synthesized nanoparticles it has become necessary for the researchers to find innovative methods for their synthesis and to further analyze their toxicity and inhibitory effects on environment and the microbial population are also recommended.

\section{ACKNOWLEDGEMENT}

I would like to show gratitude to the Deputy Registrar and the Dean of SRM-IST, NCR Campus, my HOD and colleagues who provided insights, expertise and support that greatly assisted the research,

\section{REFERENCES}

1. Beach, E. S., Cui, Z. and Anastas, P. T., 4. Hutchison, J.E., ACS Sustainable Chem. Eng., Energy Environ. Sci., 2009, 2, 1038,.

2. Tyagi, S., J.of Pharmaceutics and Nanotechnology., 2016, 4,102,.

3. Kessler, R., Environ Health Perspect., 2011, 119, A120.

2016, 4, 5907 .

5. Roco, M., Springer Netherlands., 2011, 1, 1.

6. Fleischer, T. and Grunwald, A., J. Clean. Prod., 2008, $16,889$.

7. Koo, O.M., Rubinstein, I. and Onyuksel, H., Nanomedicine., 2005, 1, 193. 
8. Alaqad, K . and Saleh, T.A., J Environ Anal Toxicol, 2016, 6, 384.

9. Sengul, H., Theis, T. L. and Ghosh, S., J. Ind. Ecol., 2008, 12, 329.

10. Saleh, T. A., Bioenergetics., 2016, 5, 226; doi:10.4172/2167-7662.1000226

11. Tsuzuki, T., Int. J. of Nanotech., 2009 , 6, 567.

12. Liu, Z., Wang, R., Kan, F. and Jiang, F., Asian J. of Chemistry.,2014, 26,655.

13. Makarov,V.V., Love,J., Sinitsyna,O.V., Makarova, S. S. and Yaminsky, I. V., Acta naturae., 2014, 6, 35.

14. Ibrahim, H.M.M., J. Radiat. Res. Appl. Sci., 2015, 8, 265.

15. Verma, A. and Mehata, M. S., J. Radiat Res Appl Sci.,2016, 9,109.

16. Sameh, S. A., J. Nanomedine Biotherapeutic Discov., 2012, 2, 110.

17. Valter, B . and Claudio, N. J Nanomed Nanotechnol., 2014, 5, 230.0.

18. Kepley, C., J Nanomed Nanotechnol., 2012, 3, 111.

19. Annamalai, J. and Nallamuthu, T., Applied Nanosc., 2016, 6, 259.

20. Jibowu, T., J. Nanomed Nanotechnol., 2016, 7, 379.

21. Arun, G., Eyini, M. and Gunasekaran, P.,Biotechnol Bioprocess Eng., 2014, 19, 1083.

22. Salehi, S., Shandiz, S. A. S. and Ghanbar, F., Int J Nanomedicine., 2016, 11,1835.

23. Le, X. and Poinern, G.E.J., Subramaniam, S. and Fawcett, D., Open J. Biomed. Mater. Res., 2015, 2, 11.

24. Demir, E., Hereditary Genet., 2015, 4,151.

25. Nikalje, A. P., Med Chem., 2015, 5, 081.

26. Boisselier, E. and Astruc, D., Chem Soc. Rev., 2009, 38, 1759.

27. Ghashghaei, S. and Emtiazi, G., J Nanomater Mol Nanotechnol., 2013, 2, 5.

28. Hartung, G.A. and Mansoori, G.A., J Nanomater Mol Nanotechnol., 2013, 2, 3.

29. Murugan, Kumara, A., K. and Sundaram, S., World J. Pharm. pharm. Sci., 2014, 3, 1385.

30. Masala, O. and Seshadri, R., Annu Rev Mater Res., 2004, 34, 41.

31. Castiglione, M.R. and Cremonini, R., Caryologia., 2009, 62, 161.

32. Densica,U.V., Gamulin, O., Tonej,A., Ivanda,M., White,C.W., Sonder,E. and
Zuhr,R.A.., Mat. Sci. Engg., 2011, 15, 105.

33. Shahwan,T., Sirriah,S.A., Nairat,M., Boyaci, E., Eroglu, A.E., Scott T.B and Hallam, K.R., Chem Eng J., 2011, 172, 258.

34. Daniel,S.K.,Vinothini,G., Subramanian,N., Nehru,K. and Sivakumar, M., J Nanopart Res., 2013, 15, 1.

35. Iravani,S., Int. Scholarly Res. Notices., 2014, 359316, 18; http://dx.doi.org/ 10.1155/ 2014/ 359316 .

36. Mohanpuria, P., Rana, K.N. and Yadav, S.K., J. Nanopart. Res., 2008, 10, 507- 517.

37. Oksanen T., Pere J., Paavilainen L., Buchert and J. Viikari L., J. Biotechnol., 2000, 78, 39.

38. Vahabi, K., Mansoori, G.L. and Karimi, S.S., Insci. J., 2011, 1, 65.

39. Saxena, J., Sharma,M.M., Gupta,S. and Singh,A., World J. Pharmacy Pharmaceutical Sci., 2014, 3,1586.

40. Cundy, A. B., Hopkinson, L. and Whitby, R.L.D., Sci. Total Environ., 2008, 400, 42e51.

41. Berge, N. D. and Ramsburg, C.A., J. Contam. Hydrol., 2010, 118, 105e116.

42. El-Kemary, M., El-Shamy, H. and El-Mehasseb I, J. Lumin., 2010, 130, 2327.

43. Tosco,T., Papini,M.P., Viggi,C. C. and Sethi,R., J. Clean. Prod., 2014, 1, 10e21.

44. Santornchot,P., Satapanajaru,T. and Comfort,S.D., World Acad. Sci. Eng. Technol., 2010, 48, 625.

45. Yan,W., Lien,H.L., Koel,B.E. and Zhang,W.X., Environ. Sci. Process. Impacts., 2013, 15, $63 \mathrm{e} 77$.

46. Reddy,K.R., Khodadoust,A.P. and DarkoKagya,K., J. Environ. Eng., 2014, 140, 04014042. ASCE.

47. Reddy,K., Darnault,C. and K. Darko-Kagya, J. Geotechnical Geoenvironmental Eng., 2014, 140, 04013013.

48. Nel,A., Xia,T., Madler,L. and Li,N., Science., 2006, 311, 622e627.

49. Reardon, E, J., Fagan, R., Vogan, J. L. and Przepiora, A., Environ. Sci. Technol., 2008, 42, 2420e2425.

50. Grieger,K.D., Fjordboge,A., Hartmann,N.B., Eriksson,E., Bjerg,P.L. and Baun, A., J. Contam. Hydrol., 2010, 118, 165e1830.

51. Gordon,T. and Margel,S., Colloids Surf. Physicochem Eng. Asp., 2011, 374, $1 \mathrm{e} 8$.

52. Li,H. and Jiang, G., Ecotoxicol. Environ. Saf., 2009, 72, 684e692. 
53. Xiu,Z. and Alvarez,P. J. J., Bioresour. Technol., 2010, 101, 1141e1146.

54. Kirschling,T.L. and Tilton, R. D., Environ. Sci. Technol., 2010, 44, 3474e3480.

55. Bokare,V., Murugesan,K., Kim,J.H., Kim,E. J. and Chang,Y.S., Sci. Total Environ., 2012 , 435e436, 563e566.

56. Lefevre,E., Bossa,N., Wiesner,M. and Gunsch,C., Sci. Total Environ., 2016, 15, 889e901.

57. Chen, P. J., Su,C.H., Tseng,C.Y., Tan, S.W. and Cheng, C.H., Mar. Pollut. Bull., 2011, 63, 339e346.

58. Diao,M. and Yao, M., Water Res., 2009, 43, $5243 e 5251$.

59. Shah, V. and Seal, S., J. Hazard Mater., 2010, 178, 1141e1145.

60. Khan,S. S., Kumar,E.B., Mukherjee,A. and Chandrasekaran,N., J. Basic Microbiol., 2011, 51, 183e190.

61. Wu,D., Shen, Y., Ding,A., Mahmood,Q., Liu,S. and Tu,Q., J. Hazard. Mater., 2013, 262, 649 e655.

62. Kim,Y.M., Murugesan,K., Chang,Y.Y., Kim,E.J. and Chang,Y.S., J. Chem. Technol. Biotechnol., 2011, 87, $216 \mathrm{e} 224$.

63. Le,T.T., Nguyen,K.H., Jeon,J.R., Francis,A.J. and Chang,Y.S., J. Hazard. Mater., 2015 , 287, 335e341.

64. Nemecek,J., Pokorny,P., Lhotsky,O., Knytl,V., Najmanova,P., Steinova, J., Cerník,M., Filipova,A., Filip, J. and Cajthaml, T., Sci. Total Environ., 2016, 563e564, 822e834.

65. Dinesh,R., Anandaraj,M., Srinivasan,V. and Hamza,S., Geoderma., 2012, 173e174, $19 \mathrm{e} 27$.

66. Koenig,J.C., Boparai,H.K., Lee,M.J., O'Carroll,D.M., Barnes,R.J. and Manefield, M. J., J. Hazard. Mater., 2016, 308, $106 \mathrm{e} 112$.

67. Bokare,V., Murugesan,K., Kim,Y.-M., Jeon,J.-R., Kim,E.-J. and Chang,Y.S., Bioresour. Technol., 2010, 111, 6354e6360.

68. Singh,R., Manickam,N., Mudiam,M .K. R., Murthy,R. C. and Misra,V., J. Hazard. Mater., 2013, 35, 258e259.

69. Padma,P.N., Banu,S.T., and Kumari,S.C., Annual Research \& Review in Biology, 2018, 23. 1;doi:10.9734/ARRB/2018/38894.

70. Minal, S. and Prakash, S., Int.J.of Adv.Eng. and Nano Tech.(TM)., 2018, 3,2347.

71. Petla,R.K., Vivekanandhan,S., Misra,M., Mohanty,A.K., and Satyanarayana,N., J Biom. R Nanobio., 2012, 3, 14.
72. Nadagouda,M.N., and Varma,R.S., Green Chemistry., 2008, 10, 859.

73. Haritha,E., Roopan,S.M., Madhavi,G., Elango,G., Al-Dhabi,N.A., and Arasu, M. V., J.of Cluster Science., 2017, 28, 1225.

74. Seyedi,N., Saidi,K., and Sheibani,H.,Catalysis Letters., 2018, 148, 277.

75. Bhakyaraj,K., Kumaraguru,S., Gopinath,K., Sabitha,V., Kaleeswarran,P.R., Karthika,V., Sudha,A., Muthukumaran, U., Jayakumar,K., Mohan,S., and Arumugam,A., J.of Cluster Science., 2017, 28, 463.

76. Li,G., Li,Y., Wang,Z. and Liu,H., Materials Chemistry and Physics., 2017 187, 1330; https:// doi.org/10.1016/j.matchemphys. 2016.11.057.

77. Soni,N. and Prakash,S., Parasitology research., 2012, 110, 175.

78. Soni,N. and Prakash,S., Rep Parasitol., 2012, 2, 1.

79. Soni,N. and Prakash,S.,Parasitology research., 2012, 111, 2091.

80. Soni,N. and Prakash,S.,Annals of microbiology., 2014, 64,1099.

81. Soni,N. and Prakash,S., Parasitology research., 2015, 114, 1023.

82. Morrison,S.J., Metzler,D.R. and Dwyer, B. P., J. Contam. Hydrol., 2002, 56, 99.

83. Lam,S.J., Wong,E.H.H., Boyer,C. and Qiao,G.G., Progress in Polymer Science., 2018, 76, 40; https://doi.org/10.1016/j. progpolymsci.2017.07.007

84. Dimitrov,D., Colloids Surf. A., 2006, 8, 282.

85. Kavitha,K.S., Baker,S., Rakshith,D., Kavitha, H.U., Rao, H.C.Y., Harini, B.P. and Satish,S., Int. Res. J. Bio. Sci., 2013, 2, 66.

86. Rasheed,T., Bilal,M., Iqbal,H.M.N. and Li,C., Colloids Surf B Biointerfaces., 2017, 158, 408; doi: 10.1016/j.colsurfb.2017.07.020.

87. Kumar,R.R., Priyadharsani,K.P.andThamaraiselvi, K., J Nanopart Res., 2012 , 14(5), 1.

88. Singh,R.P., Magesh,S. and Rakkiyappan,C., Int J Bioeng SciTechnol., 2011, 2, 64.

89. Vijayakumar,M., Priya,K., Nancy, F.T., Noorlidah,A. and Ahmed, A. B. A., Ind Crop Prod., 2013, 41, 235.

90. Ramya,S., Neethirajan,K., and Jayakumararaj, R., J. Pharm. Res., 2012, 5, 4548.

91. Zia,F., Ghafoor, N., Iqbal, M. and Mehboob, S., Appl. Nanosci., 2016, 6,1023. 
92. Mubayi,A., Chatterji,S., Rai,P.M., and Watal,G., Adv. Mat. Lett., 2012, 3, 519.

93. Karuppiah, M. and Rajmohan, R., Materials Letters., 2013, 97,141.

94. Bououdina, M.S., Rashdan, J.L., Bobet, Ichiyanagi,Y., J. Nanomater., 2013, 240, 8501.

95. Vidhu,V.K., Aromal,S.A., and Philip,D., Spectrochim. Acta Part A: Mol. and Biomol. Spect., 2011, 83,392.

96. Cheirmadurai,K., Biswas,S., Murali,R. and Thanikaivelan,P., RSC Adv., 2014, 4, 19507; doi:10.1039/C4RA01414F.

97. Mittal, A.K., Chisti,Y., and Banerjee,U.C., Biotechnol. Adv., 2013, 31,346.

98. Rajoriya,P., Misra,P., Shukla,P.K., and Ramteke, P. W., Curr. Sci., 2016, 111,1364.

99. Jayaseelan,C., Ramkumar,R. and Rahuman,A.A., Indust. Crops and Prod., 2013, 45, 423.

100. Saeb,A.T. M., Alshammari,A.S., Al-Brahim,H., and Al-Rubeaan,K A., The Scientific World J., 2014, 9,; ArticlelD704708.

101. Mendoza-Res'endez,R., Nũnez,N.O., Barriga-Castro,E.D., and Luna,C., RSC Advances., 2013, 3, 20765.

102. Vadlapudi,V., Kaladhar,D.S.V.G.K., Behara,M., Sujatha B. and Naidu,G.K., Orient. J. Chem., 2013, 29, 1589.

103. Shameli,K., Ahmad,M.B., Jaffar AlMulla,E. A., Ibrahim,N.A., Shabanzadeh,P., Rustaiyan,A., Abdollahi,Y., Bagheri,S., Abdolmohammadi,S., Usman,M.S., Zidan,M., Molecules., 2012, 17,8506.

104. Basavegowda,N., Idhayadhulla,A., and Lee,Y. R., Mat.Lett., 2014, 129, 28.

105. Mizuhara,T., Moyano,D.F, and Rotello,V.M., Nano Today., 2016, 11, 31; https://doi. org/10.1016/j.nantod.2015.11.002.

106. Saxena,A., Tripathi,R. M., Zafar,F., and P. Singh, Mat.Lett., 2012, 67, 91.

107. Iravani,S., Zolfaghari,B., Biomed. Res. Int., 2013, Article ID 639725,(2013);doi: 10.1155/2013/639725.

108. Patra,S., Mukherjee,S., Barui,A.K., Ganguly,A., Sreedhar,B. and Patra,C.R., Mater. Sci. Eng. C., 2015, 53, 298.

109. Siddiqui,M.H., Al-Whaibi,M.H., Firoz,M., and. Al-Khaishany,M.Y., Role of Nanoparticles in Plants in Nanotechnology and Plant Sciences, ( ) Springer International Publishing
Switzerland., 2015.

110. Beyene,H.D., Werkneh,A.A., Bezabh,H.K., Ambaye,T.G., Sustainable Materials and Technologies., 2017, 13, 18.

111. Kumar,D., Karthik,L., Kumar,G. and Roa, K. B. Pharmacology online., 2011, 3, 31100.

112. Tripathi,V., Fraceto,L.F., and Abhilas,P.C., Ecological Engineering., 2015, 82, 330.

113. Alani,F., Moo-Young,M., and Anderson,W., World J Microbiol Biotechnol., 2012 28, 1081.

114. Durán,N., Marcato,P.D., Durán,M., Yadav,A., Gade,A. and Rai, M., Appl. Microbiol. Biotechnol., 2011, 90, 1609.

115. Krishnaswamy,K., Vali,H. and Orsat, V. J., J. Food Eng., 2014, 142, 210.

116. Nanda,A. and Saravanan,M., Nanomed Nanotechnol Biol Med., 2009, 5, 452.

117. Kalishwaralal,K., Deepak,V., Pandian,S.R.K., Kottaisamy,M., Mani Kanth,S., Kartikeyan,B. and Gurunathan,S., Colloids SurfB., 2010, 77, 257.

118. Calderon,B. and Fullana,A., A. Water Res., 2015, 83, 1.

119. Chaturvedi,V. and Verma,P., Bioresour Bioprocess., 2015, 2,18.

120. Subbaiya,R., Shiyamala,M., Revathi,K., Pushpalatha, R. and Selvam, M .M., Int J. Curr Microbiol App Sci., 2014, 3, 83.

121. Manivasagan,P., Venkatesan,J., Sivakumar,K. and Kim, S.K., Crit. Rev. Microbiol., 2016, 42, 209.

122. Sinha,S., Paul,N,D., Halder,N., Sengupta,D. and Patra Patra, S. K., Appl Nanosci., 2015, 5, 703.

123. Pasca,R.D., Mocanu,A., Cobzac,S.C., Petean,I., Horovitz,O., and TomoaiaCotisel,M., Particulate Sc. and Tech., An Int. Journal., 2014, 32, 131.

124. Jha,A.K. and Prasad,K., Int.J. of Green Nanotechnology., 2013, 4, 219.

125. Mishra,A.N., Bhadauria,S., Gaur,M.S., Pasricha,R. and Kushwah,B.S., Int. J. of Green Nanotech.:Physics and Chemistry., 2010, 1, 118.

126. Suman,T.Y., Rajasree,S.R.R., Ramkumar,R., Rajthilak,C., and Perumal,P., Spectrochimic. Acta Part A Mol. Biomol. Spectrosc., 2014, 1, 18.

127. Song,J.Y., Jang,H.K., and Kim,B.S., Korean J. Chem. Eng., 2008, 25, 808.

128. Sheny,D.S., Mathew,J., and Philip,D., Spectrochim. Acta Part A Mol. Biomol. Spectrosc., 2011, 79, 254.

129. Yadav, K.K., J. of Mat. and Env. Science., 2017 8,740 . 
130. Balaji,D.S., Basavaraja,S., Deshpande,R., Mahesh,D.B.,Prabhakar,B.K.andVenkataraman,A., Colloids Surf B., 2009 , 68, 88.

131. Park,Y., Hong,Y.N., Weyers,A., Kim,Y.S. and Linhardt,R.J., IET Nanobiotechnol., 2011, 5, 69.

132. Ahmad,A., Senapati,S., Khan,M.I., Kumar,R., Ramani,R., Srinivas, V. and Sastry,M., Nanotechnology., 2003, 14, 824,; doi:/10.1088/0957-4484/14/7/323.

133. Balagurunathan,R., Radhakrishnan,M., Rajendran,R.B. and Velmurugan, D., Indian J Biochem Biophys., 2011, 48, 331.

134. Kuppusamy,P., Yousoff,M.M., Manian,G.P. and Govindan,N., Saudi Pharm J., 2014, 24, 473, ; doi:10.1016/j.jsps.2014.11.013.

135. Ahmad,A., Senapati,S., Khan,M.I., Kumar,R. and Sastry, M., Langmuir, 2003, 19, 3550, 135.

136. Malarkodi,C., Rajeshkumar,S., Vanaja,M., Paulkumar,K., Gnanajobitha,G. and Annadurai,G., J Nanostruct Chem., 2013, 3, 1.

137. Narayanan,K. and Sakthivel,N., World J. Microbiol. Biotechnol., 2013, 29, 2207.

138. He,S., Guo,Z., Zhang,Y., Zhang,S., Wang, J. and Gu,N., Mater Lett., 2007, 61,3984.

139. Castro-Longoria,E., Vilchis-Nestor,A.R. and Avalos-Borja,M., Colloids Surf. B Biointerfaces., 2011, 83, 42.

140. Mishra,A., Tripathy,S., Wahab,R., Jeong,S.H., Hwang,I., Yang,Y.B., Kim,Y.S., Shin,H.S. and Yun,S.I., Appl. Microbiol. Biotechnol., 2011,92,617.

141. Saravanan,M. and Nanda,A., Colloids Surf. B Biointerfaces., 2010, 77, 214.

142. Kanchi,S., Kumar,G.K., Lo,An-Ya., Tseng,C.M., Chen,S.K., Lin,C.Y. and Chin,T.S., Arab. J. of Chem., 2018, 11, 247; https://doi. org/10.1016/j.arabjc.2014.08.006.

143. Zha,J., Dong,C., Wang,X., Zhang,X., Xiao,X. and Yang,X., Optik - Int. J.for Light and Electron Optics., 2017, 144, 511 ; https://doi. org/10.1016/j.ijleo.2017.06.088

144. Kumar,K.P., Paul,W. and Sharma, C.P., Process Biochem., 2011, 46, 2007.

145. Mishra,S., Dixit,S., Soni,S., Bio-Nanoparticles: Biosynth. Sustain. Biotechnological. Implications., 2015, 20, 141,; doi:101002/ 9781118677629.ch7.

146. Kumar,K.M., Sinha,M., Mandal,B.K., Ghosh,A.R., Kumar,K.S. and Reddy,P.S., Spectrochimica Acta Part A:Mol. and Biomol. Spectroscopy., 2012, 91,228.
147. Kumar,K.M., Mandal,B.K., Sinha,M. and Krishnakumar, V, Spectrochimica Acta Part A: Molecular and Biomolecular Spectroscopy., 2012, 86, 490.

148. Phumying,S., Labuayai,S., Thomas, C., Amornkitbamrung,V., Swatsitang, E. and Maensiri,S., Appl Phys A., 2013, 111, 1187.

149. Njagi,C.E., Huang,H., Stafford,L., Genuino,H., Galindo,M.H., Collins, B.J., Hoag, E.G. and Suib, L.S. Langmuir., 201, 27, 264.

150. Latha N, Gowri M. Int J Sci Res., 2014, 3, 1551.

151. Mahdavi,M., Namvar,F., Ahmad,M.B. and Mohammad, R., Molecules., 2013, 18, 5954.

152. Pattanayak,M. and Nayak,P.L., World J. Nano Sci. Technol., 2013, 2(1), 0609.

153. Narayanan,K.B. and Sakthivel, N., J Hazard Mater., 2011, 189, 519.

154. Binupriya,A.R., Sathishkumar,M., Vijayaraghavan,K. and Yun,S.I., J Hazard Mate., 2010, 177, 539.

155. Elcey,C., Kuruvilla,A.T. and Thomas,D., Int. J. Curr. Microbiol. Appl. Sci., 2014, 3,408.

156. Arcon,I., Piccolo,O., Paganelli,S. and Baldi, F., Biometals., 2012, 25(5),875.

157. Kaul,R., Kumar,P., Burman,U., Joshi,P., Agrawal,A., Raliya,R. and Tarafdar, J., Mater Sci-Poland., 2012, 30,254.

158. Laokul,P. and Maensiri,S., J. of optoelecronics and Adv. Mat., 2009, 11, 857.

159. Phumying,S., Labuayai,S., Swatsitang,E., Amornkitbamrung,V. and Maensiri,S., Mat. Res. Bull., 2013, 48, 2060.

160. Taranath, T.C. and Patil,B.N., Int. J. Mycobacteriol., 2016, 5, 197; 10.1016/j. ijmyco. 2016.03.0041

161. Jamdagni,P., Khatri,P., Rana,J.S., J. King Saud Univ.-Sci., 2016, 30, 168;doi 10.1016/j. jksus.2016.10.002

162. Sundrarajan,M., Ambika,S., Bharathi,K., Adv. Powder Technol., 2015, 26, 1294;10.1016/j. apt.2015.07.001

163. Rajiv,P., Rajeshwari,S., Venckatesh,R., Spectrochimica Acta-Part A., 2013, 112, 384; 10.1016/j.saa.2013.04.072

164. Vijayakumar,S., Vinoj,G., Malaikozhundan,B., Shanthi,S. and B.Vaseeharan., Spectrochimica Acta-Part A., 2015, 137, 886; 10.1016/j. saa.2014.08.064

165. Dobrucka,R., Długaszewska,J., Saudi J. Biol. Sci., 2016, 23, 517; 10.1016/j.sjbs.2015.05.016 
166. Yedurkar,S., Maurya,C., Mahanwar,P., Open J. Synth. Theory Appl., 2016, 5, 1; 10.4236/ ojsta.2016.51001

167. Zhang,W-X., J. of Nanoparticle Res., 2003 , $5,323$.

168. Lee,C., Kim,J.Y., Lee,W.I., Nelson,K.L., Yoon,J., Sedlak,D.L., Environ Sci. Technol., 2008, 42, 4927.

169. Raliya, R., Tarafdar, J. C., Int. Nano Lett., 2014, $4,1$.

170. Raliya,R., Tarafdar, J. C., Agri. Res., 2013, 2, 48,

171. Xu,J-C., Mei,L., Guo,X-Y., and Li,H-U., J. of Molecular Catalysis A: Chemical., 2005, 226,123.

172. Mazumdar,H., Haloi,N., J. Microbiol Biotechnol Res., 2011, 1,39.

173. Kaur,P., Thakur,R., Chaudhury,A., Green Chem. Let. and Rev., 2016, 9, 33.

174. Kulkarni,V., and Kulkarni,P., Nano Sc. and Nano Tech., 2014, 8, 401.

175. Dashora,A., Sharma,K., Adv.Sc.Eng.and Med., 2018, 10, 523.

176. El-Refai,A.A., Ghoniem,G.A., El-Khateeb,A.Y. and Hassan,M.M., J Nanostruct. Chem., 2018, 8, 71; https://doi.org/10.1007/s40097018-0255-8

177. Kulkarni,D.V., Kulkarni,P.S., Int. J. of Chem. Stud., 2013, 1, 3.

178. Naika,H.R., Lingaraju,K., Manjunath,K., Kumar,D., Nagaraju,G., Suresh,D., Nagabhushana,H., J.of Taibah Univ. for Science., 2015, 9, 7.

179. Sivaraj,R., Rahman,P.K., Rajiv,P., Salam,H.A., Venckatesh,R., Spectrochimica Acta Part A: Molecu. and Biomol. Spect., 2014, 133, 178.

180. Sharma,J.K., Akhtar,M.S., Ameen,S., Srivastava,P., Singh,G., J.of Alloys and Compounds., 2015, 632, 321.

181. Sankar,R., Maheswari,R., Karthik,S., Shivashangari, K.S., Ravikumar,V., Materials Science and Engineering: C., 2014, 44, 234.

182. Sankar,R., Manikandan,P., Malarvizhi,V., Fathima,T., Shivashangari,K.S. and Ravikumar,V., Spectrochimica Acta Part A: Molecular and Biomolecular Spectroscopy., 2014, 121, 746.

183. Kumar,B., Smita,K., Cumbal,L., Debut,A. and Angulo,Y., J.of Saudi Chemical Society.,
2017, 21, S475.

184. Wang,T., Lin,J., Chen,Z., Megharaj,M. and Naidu, R., J.of Cleaner Production., 2014 , 83,413

185. Shobha,G., Moses,V., Ananda,S., Int. J. Pharm. Sci. Invent., 2014, 3(28), 3.

186. Kim,A., Muthuchamy,N., Yoon,C., Joo, S. and Park, K., Nanomaterials., 2018, 8, 138.

187. Varshney,R., Seema,B., Gaur,M.S., Pasricha, R., J.of Metals., 2010, 62(102), 187.

188. Parveen,F., Sannakki,B., Mandke,M.V., Pathan,H.M., Solar Energy Materials and Solar Cells, 2016, 144, 371; https://doi. org/10.1016/j.solmat.2015.08.033188.

189. Umer,A., Naveed,S. and Ramzan,N., World Sci. Publ. Company., 2012, 7, 18.

190. Majumder,B.R., Int. J.of Eng.Sci.and Tech., 2012, 4, 4380.

191. Salvadori,M.R., Ando,R.A., Nascimento,C.A.O. and Corrêa,B.,PLOS ONE,9, e87968., 2014.

192. Honary,S., Barabadi,H., Fathabad,E.G. and Naghibi,F., Dig. J.of Nanomat. and Biostruc., 2012, 7, 999.

193. Cuevas,R., Durán,N., Diez,M.C., Tortella,G.R.O. and Rubilar, O., Journal of Nanomaterials., 2015, 2015, 1.

194. Abboud, Y., Saffaj, T., Chagraoui, A., Bouari, E., Brouzi, K., Tanane, O., Ihssane, B., Applied Nanoscience., 2014, 4, 571.

195. Sivaranjani,V. and Philominathan,P., Wound Medicine., 2015, 12, 1.

196. Sundrarajan,M. and Gowri,S., Chalcogenide Letters., 2011, 8, 447.

197. Subhapriya,S. and Gomathipriya,P., Microb. Pathog., 2018, 116, 215; DOI: 10.1016/j. micpath.2018.01.027

198. Rai,P.K., Kumar,V., Lee,S.S., Raza,N., Kim,K.H., Ok,Y.S. and Tsang,D.C.W., Environment International., 2018, 119, 1.

199. Rajakumar,G.I., Rahuman,A.A., Jayaseelan,C., Santhoshkumar,T., Marimuthu,S., Kamaraj,C., Bagavan,A., Zahir,A.A., Kirthi,A.A., Elango,G., Arora,P., Karthikeyan,R., Manikandan,S. and S. Jose, Parasitol Res., 2014, 113, 469;doi: 10.1007/s00436-013-3676

200. VishnuKirthi,A., AbdulRahuman,G., Rajakumar,S., Marimuthu,T., Santhoshkumar, C., Jayaseelan,G., Elango,A., AbduzZahir,C. and Kamarajbagawan,A., Materials Letters., 2011., 65, 2745. 
201. Khan,R. and Fuleka,M.H., Journal of Colloid and Interface Science., 2016, 475, 184.

202. Jayaseelan,C., Rahuman,A.A., Roopan,S.M., Kirthia,A.V., Kim,Se-K., Iyappan,M.and Siva,C., Spectrochimica Acta Part A: Molecular and Biomolecular Spect., 2013 107, 82.

203. Tarafdar,A., Raliya,R., Wang,W.-N., Biswas,P. and Tarafdar, J., Adv. Sci. Eng. Med., 2013, 5, 943.

204. Subramanyam,S.G. and Siva,K., Int. J.of Life Sciences Res., 2016, 4, 69.

205. Raliya,R., Rathore, I. and Tarafdar, J. C., J. Bionanosci., 2013, 7, 59.

206. Jia,L., Zhang,Q., Li,Q. and H. Song, Nanotechnology., 2009, 20, 385601.

207. Yang,X., Li,Q., Wang,H., Huang, J., Lin,L., Wang,W., Sun,D., Su,Y., Opiyo,J.B., Hong,L. and Y.Wang, J. of Nanopart. Res., 2010 , 12, 1589.

208. Rajakumar,G., Rahuman,A.A., Chung,I., Kirthi,A.V., Marimuthu,S. and K. Anbarasan, Parasitology research., 2015, 114,1397.

209. Minal,S. P. and Prakash,S., Int. J. of Adv. Eng. and Nano Tech., 2018, 3,1.

210. Shaik,M.R., Ali,Z.J.Q., Khan,M., Kuniyil,M., Assal,M.E., Alkhathlan, H.Z., Warthan, A.A., Siddiqui, M.R.H., Khan,M., Farooq, S. and Adil, S. F., Molecules., 2017, 22, 165.

211. Wang,Z., Fang,C. and Megharaj,M., ACS Sustain Chem Eng., 2014, 2,1022.

212. Kharissova,O.V., Dias,H.V.R., Kharisov,B.I., Pérez,B.O., JiménezPérez,V. M., Trends in Biotechnology., 2013, 31, 240.

213. Gurunathan,S., Kim,E., Han, J.W., Park, J. H. and Kim, J.H., Molecules., 2015, 20, 22476.

214. Yadav,D., Kumar,P., Kapur,M. and Mondal,M.K., Environ. prog. and sustain.energy, May., 2018; https://doi.org/10.1002/ep.12920

215. Zhang,W-X., Soy Protein and/or Soy Derivatives With Zero-Valent Iron Compositions and Use For Environmental Remediation. U.S. Patent \# US., 2009, 7(507) 345 B2.

216. Naraginti, S. and Sivakumar, A., Spectrochim Acta A Mol Biomol Spectrosc., 2014, 128; doi: 10.1016/j.saa.2014.02.083.

217. Prasad,K. and Jha, A. K., Nat. Sci., 2009, 1, 129.

218. Mashrai,A., Khanam,H. and Aljawfi,R.N., Arabian J Chem., 2013, 10, S1530; https:// doi.org/10.1016/j.arabjc.2013.05.004

219. Chong,M.N., Jin,B., Chow,C.W. and Saint,C., Water Res., 2010, 44, 2997.
220. Dastjerdi, R. and Montazer, M., Colloids Surf B., 2010, 79, 5.

221. Thome,A., Reddy,K.R., Reginatto,C. and Cecchin,I., Water, Air Soil Pollut., 2015, 226,1e20.

222. Tratnyek,P.G. and Johnson, R. L., Nano Today., 2006, 1, 44.

223. Zhang,W., Lo Irene,M.C., Liming,Hu., Voon,C.P., Lim,B.L. and Versaw, W.K., Environ. Sci. \& Tech., 2018, 52, 4385; doi: 10.1021/acs.est.7b06697

224. Zeng, S., Weng,X., Tong,Y., Lin,W. and Chen,Z., Acta Sci. Circumst., 2015, 35, 3538.

225. Xu,P., Zeng,G.M., Huang,D.L., Feng,C.L., Hu,S., Zhao,M.H., Lai,C., Wei,Z., Huang,C., Xie,G.X. and Liu,Z.F., Sci Total Environ., 2012, 424, 1, (2012); doi: 10.1016/j.scitotenv .2012 .02 .023

226. Kora,A.J. and Rastogi,L., Arabian J Chem., 2015, 2, 450.

227. Saif,S., Tahir,R. and Chen,Y., Nanomaterials., 2016,6, E209; doi: 10.3390/nano6110209.

228. S. Iravani, Green Chem., 2011, 13, 2638.

229. Yagub, M.T., Sen,T.K., Afroze,S. and Ang,H.M., Adv. Colloid Interface Sci., 2014, 209, 172.

230. Kitching,H., Kenyon,A.J. and Parkin,I.P., Phys. Chem. Chem. Phys., 2014, 16, 6050.

231. Quinn,J., Geiger,C., Clausen,C., Brooks,C. and Coon,C., Environ. Sci. Technol., 39, 1309,(2005); doi: 10.1021/es0490018

232. Nutt,M.O., Heck,K.N., Alvarez,P. and Wong,M.S., Applied Catalysis B: Environ., 2006, 69, 115.

233. Hu,L., Xia,Z., J. of Hazard. Mat., 2018, 342, 446.

234. Ahamed,M.I.N., Rajeshkumar,S., Ragul,V., Anand,S. and Kaviyarasu, K., South African J. of Chem. Eng., 2018, 25, 28.

235. Wang,X., Zhang,D., Pan,X., Lee,D-J. and G. M. Gadd, Chemosphere., 2017, 170, 266.

236. Shi,Z., Fan,D., Johnson,R.L., Tratnyek,P.G. and Williams, K.H., J.of Contaminant Hydrology., 2015, $181,17$.

237. Selvakumar,R., Ramadoss,G., Menon,M.P., Rajendran,K. and Megharaj, M., J.of Environ. Radioactivity, In press, corrected proof, Available online 7 March., 2018.

238. He, L., Wang, M., Zhang, G., Qiu, G. and Zhang, X., J.of Hazard.Mater., 2015, 294, 64.

239. Floris, B., Galloni, P., Sabuzi, F. and Conte, V., Inorganica Chimica Acta., 2017, 455,429. 
240. Alsharari,S. F., Tayel,A.A. and Moussa,S.H., Intern.J.of Biological Macromolecules, In press, corrected proof, Available online 17 July., 2018.

241. VoH,Nhat P., Ngo,H.H., Guo,W.S., Chang,S.W. and Guo, J.B., Bioresource Technology., 2018., 256, 491.

242. Song, B., Zeng, G., Gong, J., Liang, J. and Ren, X., Environment International., 2017, 105, 43.

243. Jung, H.B., Xu, H., Konishi, H. and Roden, E.E., J. of Geochem. Exploration., 2016, 169, 80.

244. Su, H., Fang, Z., Tsang, P.E., Fang, J. and Zhao, D., Environmental Pollution., 2016, 214, 94.

245. Sneh Lata and Samadder, S. R., J.of Environ. Management., 2016, 166, 387.

246. Velimirovic, M., Schmid, D., Wagner, St., Micic, V., der Kammer, F. and Hofmann,T., Science of The Total Environment., 2016, 563, 713.

247. Michálková,Z., Komárek,M., Šillerová, Puppa,H., L.D., Joussein,E., Bordas,F., Vanck,A., Vanck, O. and Ettler, V., J. of Environ. Management., 2014, 146, 226.
248. Ma,G., Salahub,S., Montemagno,C. and Abraham,S., Nano-Structures \& NanoObjects., 2018, 13, 74.

249. Campbell, K. M., Gallegos, T. J. and Landa, E. R., Applied Geochemistry., 2015, 57, 206.

250. Subbulekshmi, N. L. and Subramanian, E., J. of Environ. Chemical Eng., 2017., 5,1360.

251. Kahraman, H.T., Internat. J. of Biolog. Macromolecules., 2017., 94, 202.

252. Pandi,K., Periyasamy,S. and Viswanathan, N., Internat. J. of Biological Macromolecules., 2017., 104B,1569.

253. Asmel, N.K., Yusoff,A.R.M., Krishna,L.S., Majid,Z.A. and Salmiati,S., Chemical Eng. J., 2017., 317, 343.

254. Azzam,A.M., El-Wakeel,S.T., Mostafa,B.B. and El-Shahat, M. F., J.of Environ.Chemical Eng., 2016, 4, 2196.

255. Aguilar,Z.P., Nanomaterials for Medical Applications., 2013, 361; https://doi. org/10.1016/B978-0-12-385089-8.00008-X 